\title{
Free radical scavengers from the aerial parts of Grammosciadium platycarpum Boiss. \& Hausskn. (Apiaceae) and GC-MS analysis of the essential oils from its fruits
}

\author{
Hossein Nazemiyeh, ${ }^{1}$ Abbas Delazar, ${ }^{2}$ Nasrin Movahedin, ${ }^{1}$ Malake Jodari, ${ }^{1}$ \\ Yousef Imani, ${ }^{3}$ Mohammed-Ali Ghahramani, ${ }^{3}$ Lutfun Nahar, ${ }^{4}$ Satyajit D. Sarker ${ }^{* 5}$
}

\author{
${ }^{I}$ Research Center for Pharmaceutical Nanotechnology, Faculty of Pharmacy, \\ Tabriz University of Medical Sciences, Tabriz, Iran \\ ${ }^{2}$ School of Pharmacy, Tabriz University of Medical Sciences, Tabriz, Iran \\ ${ }^{3}$ East Azerbaijan Research Center for Agriculture and Natural Resources, Tabriz, Iran \\ ${ }^{4}$ Drug Discovery and Design Research Division, Department of Pharmacy, School of Applied Sciences, \\ University of Wolverhampton, MA Building, Wulfruna Street, Wolverhampton WV 1 1LY, England, UK \\ ${ }^{5}$ Department of Pharmacy, School of Applied Sciences, University of Wolverhampton, \\ MM Building, Molineux Street, Wolverhampton WV 1 1SB, England, UK
}

\begin{abstract}
RESUMO: "Substâncias eliminadoras de radicais livres das partes aéreas de Grammosciadium platycarpum Boiss. \& Hausskn. (Apiaceae) e análise por CG-MS dos óleos essenciais de seus frutos." Grammosciadium platycarpum Boiss. \& Hausskn (Apiaceae) é uma das três espécies endémicas no Irã do gênero Grammosciadium DC. Consumo da parte aérea da planta afeta a função renal e causa diurese. No ensaio por DPPH o extrato metanólico apresentou o maior nível de atividade de antioxidante por radicais livres $\left(\mathrm{RC}_{50}=1,196 \times 10^{-2} \mathrm{mg} / \mathrm{mL}\right)$ entre os extratos. Análises por HPLC preparativa de fase reversa do extrato metanólico resultou no isolamento de nove flavonóides, os quais foram responsáveis pela atividade de antioxidante do extrato metanólico. A análises por CG-EM dos óleos essenciais levou à identificação de 29 terpenóides, principalmente monoterpenos (não-oxigenados $3,97 \%$ e oxigenados, $77,49 \%$ ), os quais representam mais de $96 \%$ do total de óleos.
\end{abstract}

Unitermos: Grammosciadium platycarpum, Apiaceae, DPPH, antioxidante, Cg-EM, flavonoide, óleo essencial.

\begin{abstract}
Grammosciadium platycarpum Boiss. \& Hausskn (Apiaceae) is one of three endemic Iranian species of the genus Grammosciadium DC. Consumption of the aerial parts of this plant affects renal function and causes diuresis. In the DPPH assay the methanol extract showed the highest level of free radical scavenging activity $\left(\mathrm{RC}_{50}=1.196 \times 10^{-2} \mathrm{mg} / \mathrm{mL}\right)$ among the extracts. Reversed-phase preparative HPLC analyses of the methanol extract yielded nine flavonoids, which were responsible for the free radical scavenging activity of the MeOH extract. The GC-MS analyses of the essential oils led to the identification of 29 terpenoids, mainly monoterpenes (non-oxygenated $3.97 \%$ and oxygenated $77.49 \%$ ) accounting for over $96 \%$ of the total oils.
\end{abstract}

Keywords: Grammosciadium platycarpum, Apiaceae, DPPH, antioxidant, GC-MS, flavonoid, essential oils.

\section{INTRODUCTION}

Grammosciadium platycarpum Boiss. \& Hausskn (Apiaceae), a small glabrous perennial, is one of three endemic Iranian species of the genus Grammosciadium DC. (Nickavar et al., 2006; 2008). It grows abundantly in mountainous regions, especially in the slopes of Sahand Mountain (around Maragheh) of Iran (Tamamschian, 1987; Davis, 1972). It has a pleasant test and odor and is sold under the Azeri name 'Surulu' as a vegetable and food additive in the local markets during the spring. Previous studies on this species, particularly on the essential oils of the aerial parts, revealed the presence of a variety of terpenoidal compounds, and established its close relationships with the taxonomically related species G. scabridum (Sonboli et al., 2005a,b). According to common folk believes, consumption of the aerial parts of G. platycarpum affects renal function and causes diuresis. To the best of our knowledge, there is no report on the isolation of any secondary metabolites from G. platycarpum or studies on 
any pharmacological properties of this plant. As part of our on going phytochemical and pharmacological studies on Iranian medicinal plants (Delazar et al., 2009; Modaressi et al., 2009; Babaei et al., 2008; Nazemieyh et al., 2008a,b; Nazifi et al., 2008; Razvi et al., 2008), we now report on the isolation, identification and free radical scavenging properties of the compounds from the aerial parts, and GCMS analyses of the essential oils of the fruits.

\section{MATERIAL AND METHODS}

\section{General}

NMR spectra were obtained using a Bruker Spectrospin 200 and an AMX300 NMR-spectrometers. UV/visible spectra were recorded using a Shimadzu-1600 spectrophotometer. Preparative HPLC was conducted on Shimadzu -10A prep-HPLC coupled with SPDM photo diode array detector (detection at 220 and $280 \mathrm{~nm}$ ) on a CLC Shim-pack $\mathrm{C}_{18}$ column $(22 \times 250 \mathrm{~mm}, 15 \mu)$. A Shimadzu GCMS-QP5050A gas chromatograph-mass spectrometer fitted with a fused methyl silicon DB-5 column (60 $\mathrm{m} \times 0.25 \mathrm{~mm}$ i.d., $0.25 \mu \mathrm{m}$ film thickness) was used for the GC-MS analysis.

\section{Plant material}

Aerial parts of Grammosciadium platycarpum Boiss. \& Hausskn were collected during the flowering stage from Sahand region (37 30' 0.2”, 46 17'49.2"; 1870 $\mathrm{m}, 15 \mathrm{~km}$ from Maragheh to Ashan village), Iran in May 2004. The fruits were collected in August 2004 from the same place. A voucher specimen (TUM-FPh-142) for these collections has been deposited at the Herbarium of the Faculty of Pharmacy, Tabriz University of Medical Sciences.

\section{Extraction and isolation}

Fresh aerial parts $(550 \mathrm{~g})$ of $G$. platycarpum were extracted with methanol $(\mathrm{MeOH} ; 1.5 \mathrm{~L})$ for $12 \mathrm{~h}$, and the resulting extract was filtered with a Watman No.1 filter paper. The procedure was repeated three more times, filtered extracts were combined $(6 \mathrm{~L})$ and concentrated under reduced pressure. The resulting extract (27.8 g) was suspended in distilled water and re-extracted successively with $n$-hexane and dichloromethane (DCM). The solvents of all extracts including the aqueous extract were evaporated under reduced pressure at $40{ }^{\circ} \mathrm{C}$ till dryness to obtain 10.2 $\mathrm{g}$ of $n$-hexane, $7.32 \mathrm{~g}$ of DCM and $9.55 \mathrm{~g}$ of water extracts. Portions of the aqueous solution ( $3 \times 2 \mathrm{~g})$ were subjected to solid-phase extraction (Sep-Pak, $\mathrm{C}_{18}$ cartridge; $10 \mathrm{~g}$ ) using a step gradient of $\mathrm{MeOH}$-water mixtures (30:70, 60:40, 80:20 and 100:0). The resulting Sep-Pak fractions were analyzed by preparative-HPLC, eluting with a linear gradient of $\mathrm{MeOH}$-water and monitored by a photo-diode- array detector at 220 and $280 \mathrm{~nm}$. Prep-HPLC analyses (mobile phase program: linear gradient of $\mathrm{MeOH} /$ water $25: 65 \rightarrow 60: 40$ over $50 \mathrm{~min}$ followed by $60 \% \mathrm{MeOH}$ for $10 \mathrm{~min}$, flow rate: $20 \mathrm{~mL} / \mathrm{min}$ ) of the $40 \%$ methanolic SepPak fraction $(2.15 \mathrm{~g})$ afforded fractions I (collection time: from 8 to $12 \mathrm{~min}$ ) and II (collection time: from 16 to 50 $\mathrm{min})$, and compound $4(2 \mathrm{mg}, \mathrm{tR}=61 \mathrm{~min})$. Fractions I and II were further analyzed by the same system with a minor modification of the mobile phase (linear gradient of $\mathrm{MeOH} /$ water 30:70 $\rightarrow$ 40:60 over $50 \mathrm{~min}$ followed by $40 \% \mathrm{MeOH}$ for $10 \mathrm{~min}$, flow rate: $20 \mathrm{~mL} / \mathrm{min}$ ) to yield compounds 1 (3.5 mg, $t \mathrm{R}=9.6 \mathrm{~min}), 2$ (19.9 mg, $t \mathrm{R}=14.5$ $\min ), 3$ (16.7 $\mathrm{mg}, t \mathrm{R}=15.5 \mathrm{~min})$.

Similar protocol (mobile phase: linear gradient of $\mathrm{MeOH} /$ water $50: 50 \rightarrow 75: 25$ over $50 \mathrm{~min}$ followed by $75 \% \mathrm{MeOH}$ for $10 \mathrm{~min}$, flow rate: $20 \mathrm{~mL} / \mathrm{min}$ ) was applied for the $60 \%$ methanolic Sep-Pak fraction $(750 \mathrm{mg})$ to afford compounds 5 (14.2 $\mathrm{mg} ; t \mathrm{R}=20.4 \mathrm{~min}), \mathbf{6}(12.7 \mathrm{mg}$; $t \mathrm{R}=21.6 \mathrm{~min}), 7(27.1 \mathrm{mg} ; t \mathrm{R}=21.6 \mathrm{~min}), 8(3 \mathrm{mg} ; \mathrm{R}=$ $47.5 \mathrm{~min})$ and $9(7.3 \mathrm{mg} ; t \mathrm{R}=48.0 \mathrm{~min})$. The structures of the isolated compounds (1-9) were elucidated by extensive $\mathrm{UV} / \mathrm{Vis}$ spectroscopic studies using various shift reagents (Mabry et al., 1970), and by the NMR spectroscopic analyses (Figure 1). All spectroscopic data were compared with the published data.

\section{Oil extraction}

Ground dried fruits were subjected to hydrodistillation for $3 \mathrm{~h}$ using a Clevenger-type apparatus and the resulting oil was subsequently dried over anhydrous sodium sulphate.

\section{GC-MS analysis}

The GC-MS analysis was carried out on a Shimadzu GCMS-QP5050A gas chromatograph- mass spectrometer. Helium was used as carrier gas at a flow rate of $0.8 \mathrm{~mL} / \mathrm{min}$. The oven temperature was kept at $60{ }^{\circ} \mathrm{C}$ for $3 \mathrm{~min}$ and programmed to $240{ }^{\circ} \mathrm{C}$ at a rate of $2{ }^{\circ} \mathrm{C} / \mathrm{min}$ and then kept constant for $5 \mathrm{~min}$. The injector temperature was $230{ }^{\circ} \mathrm{C}$ and split ratio was adjusted at 1:57. The MS were taken at following condition: ionization potential ,70 $\mathrm{eV}$; ion source temperature, $200{ }^{\circ} \mathrm{C}$; quadrapole $100{ }^{\circ} \mathrm{C}$; solvent delay, 8 min; mass range, $25.200 \mathrm{amu}$; Em voltage; 3000 volts. Identification of the volatile oil components was carried out by comparison of their relative retention times with those of authentic samples or by comparison of their relative retention index (RRI) to series of $n$-alkane homologous series. Identification of compounds was achieved by Wiley GC-MS Library search (Adams, 2004). 
Free radical scavenging activity: the 2,2-diphenyl-1picrylhydrazyl (DPPH) assay

The free radical scavenging effect of the essential oils, the total extracts and the purified compounds was assessed using the 2,2-diphenyl-1-picrylhydrazyl (DPPH) assay (Kumarasamy et al., 2002). DPPH was obtained from Fluka Chemie AG, Bucks and a solution of DPPH (0.08 $\mathrm{mg} / \mathrm{mL})$ in chloroform $\left(\mathrm{CHCl}_{3}\right)$ was used. The essential oil was dissolved in $\mathrm{CHCl}_{3}$ to obtain the stock concentration of $1 \mathrm{mg} / \mathrm{mL}$. Dilutions were made to obtain concentrations of $5 \times 10^{-1}, 2.5 \times 10^{-1}, 1.25 \times 10^{-1}, 6.25 \times 10^{-2}, 3.13 \times 10^{-2}$ and $1.56 \times 10^{-2} \mathrm{mg} / \mathrm{mL}$. Diluted solutions $(5 \mathrm{~mL}$ each) were mixed with DPPH solution $(5 \mathrm{~mL})$ and allowed to stand for $30 \mathrm{~min}$ for any reaction to occur. The UV absorbance was recorded at $517 \mathrm{~nm}$. The experiment was performed in triplicate and the average absorption was noted for each concentration. The same procedure was followed for the positive control, quercetin.

Table 1. GC-MS analysis of the essential oils of the fruits of Grammosciadium platycarpum.

\begin{tabular}{|c|c|c|c|c|}
\hline Compounds & $\begin{array}{l}\text { Retention time } \\
t \mathrm{R} \text { in min }\end{array}$ & $\begin{array}{c}\text { Real } \% \\
\text { area }\end{array}$ & Mol. mass & $\begin{array}{l}\mathrm{M} \text { o } 1 \\
\text { formula }\end{array}$ \\
\hline Cumene & 18.53 & 0.13 & 120 & $\mathrm{C}_{9} \mathrm{H}_{12}$ \\
\hline$\beta$-Pinene & 19.24 & 0.48 & 136 & $\mathrm{C}_{10} \mathrm{H}_{16}$ \\
\hline$\beta$-Myrcene & 19.88 & 0.03 & 136 & $\mathrm{C}_{10} \mathrm{H}_{16}$ \\
\hline Hemellitol & 20.18 & 0.42 & 120 & $\mathrm{C}_{9} \mathrm{H}_{12}$ \\
\hline Phellandrene & 20.96 & 0.12 & 136 & $\mathrm{C}_{10} \mathrm{H}_{16}$ \\
\hline Mesitylene & 22.16 & 0.08 & 120 & $\mathrm{C}_{9} \mathrm{H}_{12}$ \\
\hline p-Cymene & 22.27 & 0.14 & 134 & $\mathrm{C}_{10} \mathrm{H}_{14}$ \\
\hline Bornylene & 22.62 & 1.81 & 136 & $\mathrm{C}_{10} \mathrm{H}_{16}$ \\
\hline$\beta$-Ocimene & 23.78 & 0.19 & 136 & $\mathrm{C}_{10} \mathrm{H}_{16}$ \\
\hline$\gamma$-Terpinene & 24.69 & 0.57 & 136 & $\mathrm{C}_{10} \mathrm{H}_{16}$ \\
\hline Linalool oxide A & 25.66 & 0.06 & 170 & $\mathrm{C}_{10} \mathrm{H}_{18} \mathrm{O}_{2}$ \\
\hline Linalool & 27.77 & 76.43 & 154 & $\mathrm{C}_{10} \mathrm{H}_{18} \mathrm{O}$ \\
\hline$\alpha$-Terpineol & 34.34 & 0.4 & 154 & $\mathrm{C}_{10} \mathrm{H}_{18} \mathrm{O}$ \\
\hline Geraniol & 38.69 & 0.21 & 154 & $\mathrm{C}_{10} \mathrm{H}_{18} \mathrm{O}$ \\
\hline trans -2-Decanal & 39.23 & 0.09 & 154 & $\mathrm{C}_{10} \mathrm{H}_{18} \mathrm{O}$ \\
\hline $\begin{array}{l}\text { trans- } \beta \text { - } \\
\text { Caryophyllene }\end{array}$ & 51.02 & 1.57 & 204 & $\mathrm{C}_{15} \mathrm{H}_{24}$ \\
\hline$\beta$-Farnesen & 52.80 & 0.19 & 204 & $\mathrm{C}_{15} \mathrm{H}_{24}$ \\
\hline$\alpha$-Caryophyllen & 53.28 & 0.21 & 204 & $\mathrm{C}_{15} \mathrm{H}_{24}$ \\
\hline Decalactone & 53.49 & 0.30 & 170 & $\mathrm{C}_{10} \mathrm{H}_{18} \mathrm{O}_{2}$ \\
\hline$\gamma$-Gurjunene & 54.57 & 0.05 & 204 & $\mathrm{C}_{15} \mathrm{H}_{24}$ \\
\hline$\alpha$-Farnesene & 55.27 & 1.04 & 204 & $\mathrm{C}_{15} \mathrm{H}_{24}$ \\
\hline$\gamma$-Elemene & 56.08 & 2.83 & 204 & $\mathrm{C}_{15} \mathrm{H}_{24}$ \\
\hline $\begin{array}{l}\text { Bi-1-cycloocten- } \\
1-y 1\end{array}$ & 57.63 & 0.05 & 218 & $\mathrm{C}_{16} \mathrm{H}_{26}$ \\
\hline Spathulenol & 61.20 & 1.61 & 220 & $\mathrm{C}_{15} \mathrm{H}_{24} \mathrm{O}$ \\
\hline $\begin{array}{l}\text { Caryophyllene } \\
\text { oxide }\end{array}$ & 61.62 & 0.55 & 220 & $\mathrm{C}_{15} \mathrm{H}_{26} \mathrm{O}$ \\
\hline
\end{tabular}

\begin{tabular}{lcccc}
\hline$\alpha$-Humulene & 65.90 & 6.14 & 204 & $\mathrm{C}_{15} \mathrm{H}_{24}$ \\
cis- Lanceol & 71.13 & 0.1 & 220 & $\mathrm{C}_{15} \mathrm{H}_{24} \mathrm{O}$ \\
Valerenol & 71.57 & 0.29 & 220 & $\mathrm{C}_{15} \mathrm{H}_{24} \mathrm{O}$ \\
Falcarinol & 85.57 & 1.39 & 244 & $\mathrm{C}_{17} \mathrm{H}_{24} \mathrm{O}$ \\
Monoterpenes & & 3.97 & & \\
Ox y g e n a t e d & & 77.49 & & \\
monoterpenes & & & & \\
Sesquiterpenes & & 11.08 & & \\
Ox y g e n a te d & & 3.94 & & \\
sesquiterpenes & & & & \\
Total identified & & 96.48 & & \\
\hline
\end{tabular}

Table 2. Free radical scavenging activity of the essential oils, extracts and the isolated compounds (1-9) determined by the DPPH assay.

\begin{tabular}{cc}
\hline Compounds & $\mathrm{RC}_{50}$ value in $\mathrm{mg} / \mathrm{mL}$ \\
\hline $\mathbf{1}$ & $1.09 \times 10^{-3}$ \\
$\mathbf{2}$ & $1.25 \times 10^{-3}$ \\
$\mathbf{3}$ & $1.27 \times 10^{-3}$ \\
$\mathbf{5}$ & $1.61 \times 10^{-2}$ \\
$\mathbf{6}$ & $1.49 \times 10^{-2}$ \\
$\mathbf{7}$ & $1.88 \times 10^{-3}$ \\
$\mathbf{8}$ & $3.01 \times 10^{-5}$ \\
Essential oils & 3.553 \\
$n$-Hexane extract & 1.697 \\
DCM extract & 1.387 \\
MeOH extract & $1.196 \times 10^{-2}$ \\
Positive control (quercetin) & $2.88 \times 10^{-5}$ \\
\hline
\end{tabular}

\section{RESULTS AND DISCUSSION}

Solid-phase extraction followed by reversedphase preparative HPLC analyses of the aqueous fraction of the $\mathrm{MeOH}$ extract of the aerial parts of $G$. platycarpum resulted in the isolation of nine flavonoids (1-9). Isolated flavonoid glycosides were identified as 3,4',5,6,7pentahydroxyflavone 3-O- $\beta$-D-glucopyranoside (1; Mabry et al., 1970; Wagner et al., 1976; Wenkert \& Gottlieb, 1977), 3,3',4',5,7-pentahydroxyflavone3-O- $\beta$-D-glucopyranoside (2; Mabry et al., 1970; Wagner et al., 1976; Wenkert \& Gottlieb, 1977), 3,3',4',5,7-pentahydroxyflavone 3-O- $\beta$-Dgalactopyranoside (3; Mabry et al., 1970; Datta et al., 2000), 3,3',4',5,6,7-hexahydroxyflavone (4; Mabry et al., 1970; Wagner et al., 1976; Wenkert \& Gottlieb, 1977), 3,4',5,7tetrahydroxyflavone 3-O- $\beta$-D-glucopyranoside (5; Mabry et al., 1970; Wagner et al., 1976; Wenkert \& Gottlieb, 1977), 3,4',5,7-tetrahydroxyflavone 3-O- $\alpha$-L-rhamnopyranoside (6; Mabry et al., 1970; Wagner et al., 1976; Wenkert \& Gottlieb, 1977), 3,4',5,7-tetrahydroxyflavone-3-O-(6- $p$ coumaroyl)- $\alpha$-L-rhamnopyranoside (7; Mabry et al., 1970; Wagner et al., 1976; Wenkert \& Gottlieb, 1977), quercetin (8; Mabry et al., 1970) and kaempferol (9; Mabry et al., 
1970) by extensive UV spectroscopic analyses using various shift reagents (Mabry et al., 1970), and by 1D and 2D NMR analyses. All spectroscopic data were comparable with respective published data.<smiles>[R]Oc1c(-c2ccc(O)c([R7])c2)oc2cc(O)c([R])c(O)c2c1=O</smiles>

\begin{tabular}{clll} 
Compounds & R & R' & R' \\
\hline $\mathbf{1}$ & $\mathrm{OH}$ & Glucosyl & $\mathrm{H}$ \\
\hline $\mathbf{2}$ & $\mathrm{H}$ & Glucosyl & $\mathrm{OH}$ \\
$\mathbf{3}$ & $\mathrm{H}$ & Galactosyl & $\mathrm{OH}$ \\
$\mathbf{4}$ & $\mathrm{OH}$ & $\mathrm{H}$ & $\mathrm{OH}$ \\
$\mathbf{5}$ & $\mathrm{H}$ & Glucosyl & $\mathrm{H}$ \\
$\mathbf{6}$ & $\mathrm{H}$ & Rhamnosyl & $\mathrm{H}$ \\
$\mathbf{7}$ & $\mathrm{H}$ & (6-p-coumaroyl)-rhamnosyl & $\mathrm{H}$ \\
$\mathbf{8}$ & $\mathrm{H}$ & $\mathrm{H}$ & $\mathrm{OH}$ \\
$\mathbf{9}$ & $\mathrm{H}$ & $\mathrm{H}$ & $\mathrm{H}$
\end{tabular}

The 2,2-diphenyl-1-picryl-hydrazyl (DPPH) free radical scavenging assay is based on the ability of DPPH, a stable free radical, to decolourise in the presence of free radical scavengers (antioxidants). The odd electron in the DPPH radical is responsible for the absorbance at $517 \mathrm{~nm}$, and also for visible deep purple colour (Kumarasamy et al., 2007). When DPPH accepts an electron donated by a free radical scavenger, the DPPH is decolourised, and the extent of decolourisation can be quantitatively measured from the changes in absorbance. The free radical scavenging properties of the isolated compounds (1-9), essential oils and crude extracts are summarized in Table 2. The $\mathrm{MeOH}$ extract showed the highest level of activity with a $\mathrm{RC}_{50}$ value of $1.196 \times 10^{-2} \mathrm{mg} / \mathrm{mL}$ among all extracts, and the compounds responsible for this activity were flavonoids. While the free radical scavenging properties of 1-3, 7 and 8 showed similar significant activities with the RC50 values ranging from $1.88 \times 10^{-3}$ to $1.09 \times 10^{-3} \mathrm{mg} / \mathrm{mL}$, flavonoids 5 and 6 displayed activities approximately ten-fold lower than the flavonoids $\mathbf{1 - 3}, \mathbf{7}$ or $\mathbf{8}$. Owing to the paucity of samples, the free radical scavenging activity assessment of compound 4 and 9 was not performed. The greater activity of 1-3, 7 and 8 than that of $\mathbf{5}$ and $\mathbf{6}$ was because of the presence of extra number of phenolics hydroxyl groups in those molecules.

The air-dried fruits of $G$. platycarpum provided $1.6 \%$ pale yellow essential oils. The GC-MS analyses of the essential oils led to the identification of 29 terpenoidal compounds accounting for over $96 \%$ of the total oils. The majority of components present in the oils were monoterpenes (nonoxygenated $3.97 \%$ and oxygenated $77.49 \%$ ). The amount of sesquiterpenes was about $15 \%$. Among the monoterpenes, linalool was the major component $(76.43 \%)$. This finding was significantly different from the GC-MS analyses reported earlier (Nickavar et al., 2006; 2008) where linalool was found to be the major component of fruit essential oil but the amount was significantly lower (53.9\%). However, this is not unusual to have such variations in the composition of the essential oils of plants resulting from geographical differences, growing conditions and variations in climate.

It can be concluded that the phytochemical investigation of the aerial parts of Grammosciadium platycarpum has demonstrated that this plant is a good source of flavonoids with significant free radical scavenging property, and the essential oils of the fruits predominantly contain oxygenated monoterpenes.

\section{REFERENCES}

Adams RP 2004. Identification of Essential Oil Component by Gas Chromatography/Quadrupole Mass Spectroscopy, Allured Publishing Corporation, Illinois, USA.

Babaei H, Sadeghpour O, Nahar L, Delazar A, Nazemiyeh H, Mansouri MR, Poursaeid N, Asnaashari S, Moghadam SB, Sarker SD 2008. Antioxidant and vasorelaxant activities of flavonoids from Amygdalus lycioides. Turkish J Biol 32: 203-208.

Datta BK, Datta SK, Sarker SD 2000. Quercetin 3-O-(6"galloyl)-beta-D-galactoside from Polygonum viscosum (Polygonaceae). Biochem Syst Ecol 28: 805-807.

Davis PH 1972. Flora of Turkey and East Agean Islands, Edinburgh University Press, Edinburgh, pp. 318-321.

Delazar A, Nazifi E, Movafeghi A, Nahar L, Nazemiyeh H, Moghadam SB, Asnaashari S, Sarker SD 2009. GC-MS analyses of Ornithogalum procerum. DARU 17: 33-36.

Kumarasamy Y, Fergusson M, Nahar L, Sarker SD 2002. Biological activity of moschamindole from Centaurea moschata. Pharm Biol 40: 307-310.

Kumarasamy Y, Byres M, Cox PJ, Jaspars M, Nahar L, Sarker SD 2007. Screening seeds of some Scottish plants for free-radical scavenging activity. Phytother Res 21: 615621.

Mabry TJ, Markham KR, Thomas MB 1970. The Systematic Identification of Flavonoids, Springer-Verlag, New York.

Modaressi M, Delazar A, Nazemiyeh H, Fathu-Azad E, Smith E, Rahman MM, Gibbons S, Nahar L, Sarker SD 2009. Antibacterial iridoid glucosides from Eremostachys laciniata. Phytother Res 23: 99-103.

Nazemiyeh H, Delazar A, Ghahramani M-A, Talebpour A-H, Nahar L, Sarker SD 2008a. Phenolic glycosides from Phlomis lanceolata (Lamiaceae). Nat Prod Commun 3: 53-56.

Nazemiyeh H, Bahadori F, Delazar A, Ay M., Topcu G, Kolak U, Nahar L, Majinda RRT, Sarker SD 2008b. Antioxidant phenolic compounds from the leaves of Erica arborea (Ericaceae). Nat Prod Res 22: 1385-1292. 
Nazifi E, Delazar A, Movafeghi A, Nazemiyeh H, Nahar L, Sarker SD 2008. GC-MS analysis of the dichloromethane extract of the bulbs of Ornithogalum cuspidatum Bert. (Family: Liliaceae) from Iran. Records Nat Prod 2: 94-99.

Nickavar B, Kamalinejad M, Mohandesi S 2006. Comparison of the components of the essential oils from leaves and fruits of Grammosciadium platycarpum. Chem Nat Compd 42: 686-688.

Nickavar B, Mojab F, Kamalinejad M2008. Chemical composition of the leaf and fruit oils from Grammosciadium platycarpum. Planta Med 74: 1055.

Razvi SM, Nazemiyeh H, Hajiboland R, Kumarasamy Y, Delazar A, Nahar L, Sarker SD 2008. Coumarins from the aerial parts of Prangos uloptera (Apiaceae). Rev Bras Farmacogn 18: 1-5.

Sonboli A, Eftekhar F, Yousefzadi M, Kanani MR 2005a. Antibacterial activity and chemical composition of the essential oil of Grammosciadium platycarpum Boiss. from Iran. Z Naturforsch 60c: 30-34.

Sonboli A., Salehi P, Kanani MR, Nejad-Ebrahimi S 2005b. Antibacterial and antioxidant activity and essential oil composition of Grammosciadium scabridum Boiss. from Iran. Z Naturforsch 60c: 534-38.

Tamamschian SG 1987. Grammosciadium. In: Flora Iranica, No. 162 (Rechinger, K. H., ed.). Akademische Druck- u. Verlagsanstalt, Graz, Austria, pp. 96-100.

Wagner H, Chari VM, Sonnenbichler J 1976. C-13 NMR spectra of natural flavonoids, Tetrahedron Lett 21: 1799-1802.

Wenkert E, Gottlieb HE 1977. C-13 Nuclear Magnetic Resonance spectroscopy of naturally occurring substances .49. C-13 Nuclear Magnetic Resonance spectroscopy of flavonoid and isoflavonoid compounds. Phytochemistry 16: 18111816. 